\title{
Translation and psychometric properties of the Persian version of the labor support questionnaire (LSQ)
}

\author{
Khadijeh Heidari $^{1}$, Leila Amiri-Farahani ${ }^{2,}$, Seyedeh Batool HasanpoorAzghady ${ }^{2}$, Abbas Ebadi $^{3,4}$ \\ 1. MSc Student in Midwifery, Student Research Committee, Faculty of Nursing \& Midwifery, Iran University of Medical \\ Sciences, Tehran, Iran. \\ 2.Assistant Professor, Department of Reproductive Health and Midwifery, Faculty of Nursing and Midwifery, Iran University \\ of Medical Sciences, Tehran, Iran, Tel: 02143651139, Email: amirifarahani.1@iums.ac.ir,ORCID CD:0000-0003-3128-1805 \\ 3. Professor, Behavioral Sciences Research Center, Life style institute, Baqiyatallah University of Medical Sciences, Tehran, \\ IR Iran. \\ 4. Nursing Faculty, Baqiyatallah University of Medical Sciences, Tehran, IR Iran.
}

\begin{abstract}
Background and Aim: Childbirth is one of the important events in women's life, and labor support is an important tissue, because the experience of giving birth may have a positive or negative impact on the women. Considering lack of a suitable questionnaire for measuring labor support behaviors, the present study aimed to translate and evaluate the validity and reliability of the Persian version of the labor support questionnaire.

Materials and Methods: This descriptive cross-sectional study included 213 midwives in maternity hospitals of selected medical universities in Tehran from January 2017 to September 2017. Midwives were requested to complete demographic and also labor support questionnaires. At first, we assessed the face and content validity of the instrument qualitatively, and then its construct validity was carried out by confirmatory factor analysis. In order to evaluate the reliability of the instrument, internal consistency and test-retest were used .

Results: Qualitative face and content validity of the Persian version of the labor support questionnaire were approved. Also, the construct validity of the questionnaire was confirmed by confirmatory factor analysis. Cronbach's alpha coefficient was 0.96 and the Pearson correlation coefficient of the t-test was 0.71 , which were indicative of appropriate reliability of the Persian version of the questionnaire.

Conclusion: The findings of this study showed that the Persian version of the labor support questionnaire had the necessary validity and reliability. Therefore, this questionnaire can be used as an appropriate instrument for Iranian midwives.
\end{abstract}

Keywords: Questionnaire, Validity, Reliability, Labor support behaviors, Midwife

Received: Dec8,2018

Accepted: Sep28,2019

How to cite the article: Khadijeh Heidari, Leila Amiri-Farahani, Seyedeh Batool

HasanpoorAzghady, Abbas Ebadi. Translation and psychometric properties of the Persian version of the labor support questionnaire (LSQ). SJKU 2019; 24 (5): 95-104

Copyright (C) 2018 the Author (s). Published by Kurdistan University of Medical Sciences. This is an open access article distributed under the terms of the Creative Commons Attribution-Non Commercial License 4.0 (CCBY$\mathrm{NC}$ ), where it is permissible to download, share, remix, transform, and buildup the work provided it is properly cited. The work cannot be used commercially without permission from the journal. 


\title{
ترجمه و بررسى ويخّىهاى روان سنجى نسخه فارسى ابزار رفتار هاى حمايتى ماما حين
}

\author{
ليبر)

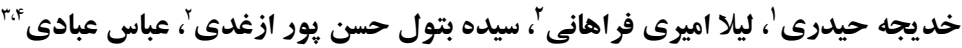

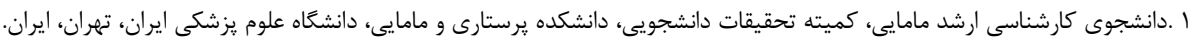

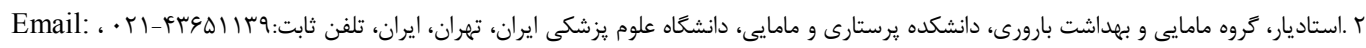

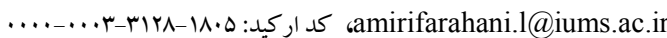

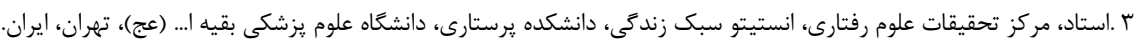

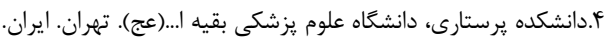

جكيuه

زمينه و هدف: زايمان، يكى از رويدادهاى مهم زندگى زنان است كه حمايت ليبر ، نقش مهمى در اين تجربه ايفـا مسى كنــ. زيـرا

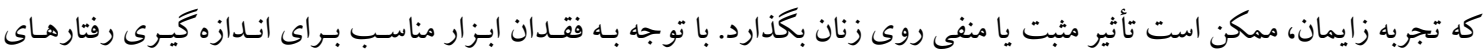

حمايتى ليبر، مطالعه حاضر با هدف، ترجمه و بررسى روايى و وايايى نسخه فارسى بر سشنامه رفتار حمايتى ماما حين ليبر انجام شد.

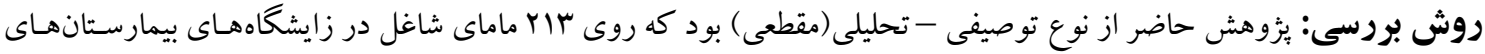

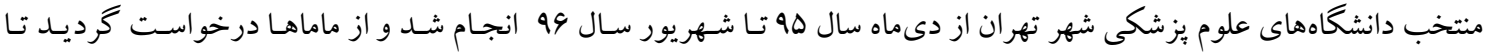

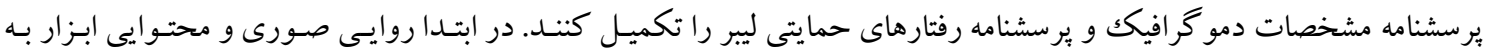

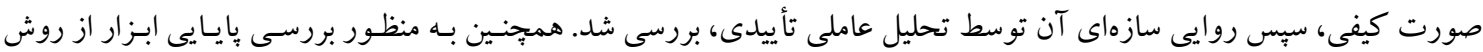

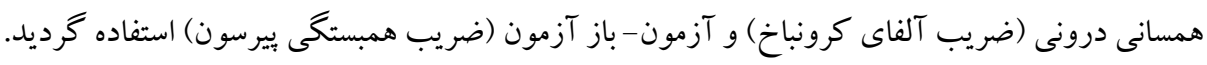

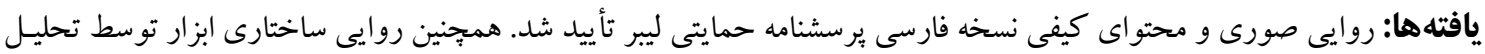

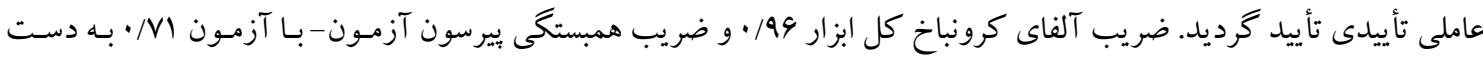

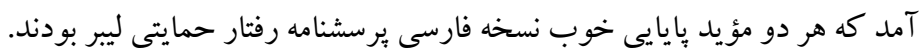

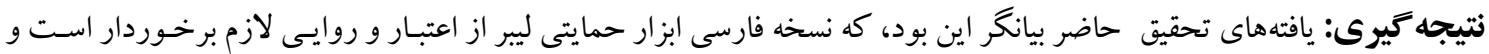

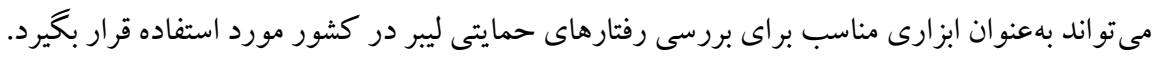

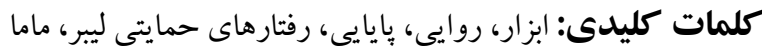
وصول مقاله:9V/9/IV 


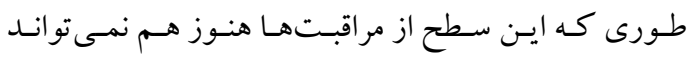

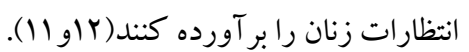

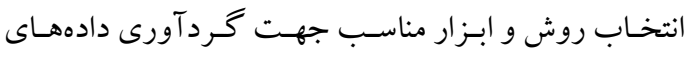
تحقيق يكى از موضوعات مهمسى اسـت كـه در طلى فر آيند

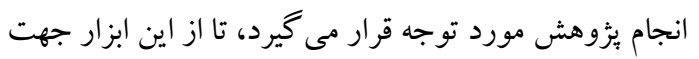

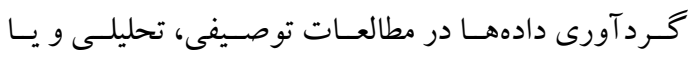

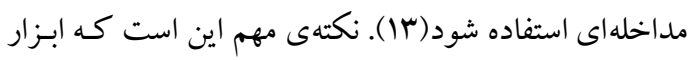

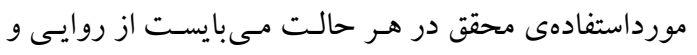

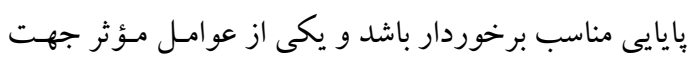

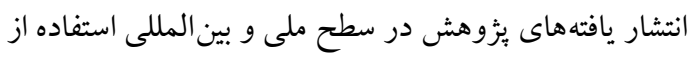

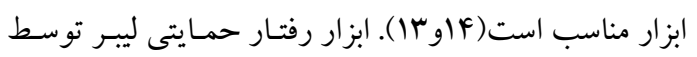

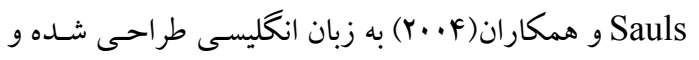
داراى روايى و ويايايى مناسب است(ها). در مطالعهاى ديخر،

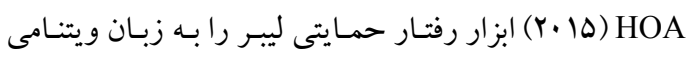
ترجمه كرد و جهت بررسى روانسنجى آن از روايسى محتسوا

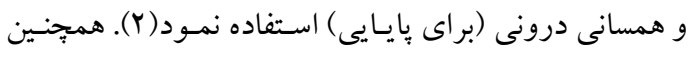

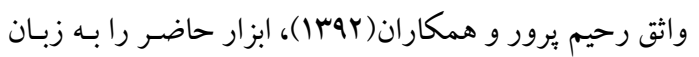

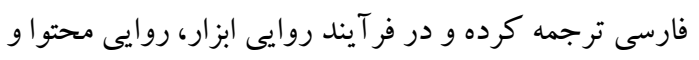

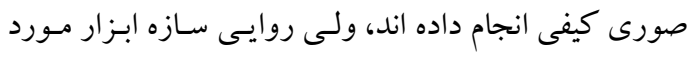

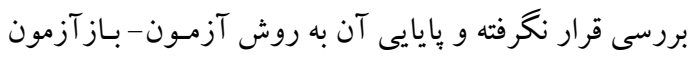

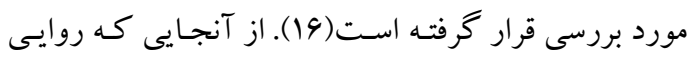

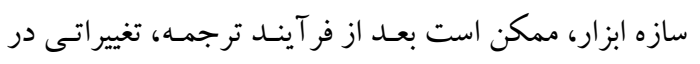

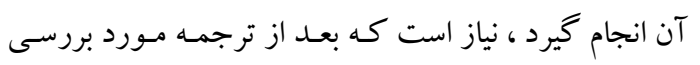

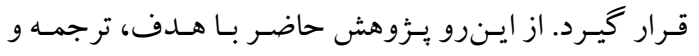
بررسى ويز گیى هاى روان سنجى نسخه فارسى ابزار رفتارهاى

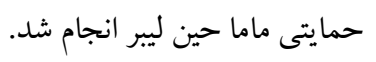

روش بررسى

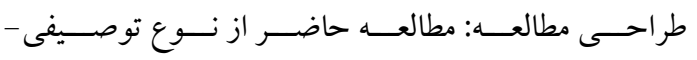
تحليلى (مقطع) بود كه روايى و پيايايى نسخه فارسى ابز مطرار
مقدمه

يكى از اهداف اختصاصسى بـراى رسـيدن بـه هـدف سـوم از اهداف توسعه هزاره، حاملكَى و زايمان ايمـن اسـت. زايمـان مى تواند اثرات روانى، اجتماعى و عاطفى بر مادر و خـانواده بحذارد. در نتيجه مديريت ليبر نقش مهمى در روند سـلامت

دو سوم از افر اد جامعه يعنى مادران و كود كان دارد(1). رفتار حمايتى ليبر به عنوان اثر متقابل بين زائو و ارائه دهنـده خدمات بهداشتى به ويزٔه مامـا كـهـ بـهـ زائو در طـول فر آينــ

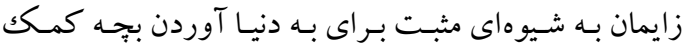
مى كند تعريف مى شود و شامل جهار بعُسد حمايـت عـاطفى، حمايت فيزيكى يا بـدنى (لمسس)، اطلاعـات و طرفـدارى' از تصميمات زائو است(Y). سابقاً اين حمايت از طرف خـانواده انجام مى گرفت كه با تغيير محل زايمان از خانه به بيمارستان و به كار گيرى مداخلات طبى، بسيارى از مـددجويان از ايـن

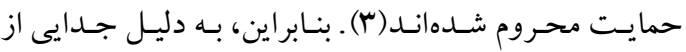
محيط امن خانـه، لازم اسـت كـه ايسن حمايـت توسـط افراد آموزش ديده از قبيل ماما انجام شود(F)، زيرا مطالعات نشان داده كه زمانى اين حمايـتهــا توسط افـراد متخصـص ارائـه

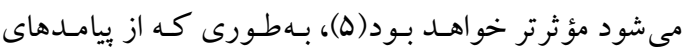
مادرى حمايت ليبر در زنان نخستزا مىتوان به افزايش ليبر، كاهش طـول زايمـان، ميـزان سـزارين، اسـتفاده از بـىدردى اييدورال، اكسى توسين، كاهش زايمان سزارين و غيره اشاره كرد(Vو 9). از طرفى، رفتـار حمـايتى ضعيف در طلى ليبـر و زايمان، موجـب افز ايش مشـكلات روحسى و روانى بعـد از

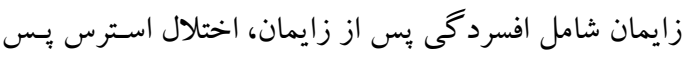

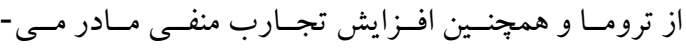
شود( يو 9). عليرغم تمام نقشهاى مثبتى كه يـك مامـا مسى -

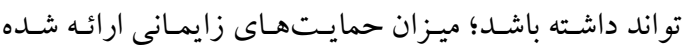

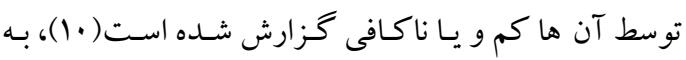


روش جمع آورى دادهها: ترجمه ابزار: ابتدا ابزار اصـلى يسس از كسب رضايت نامه از طراح برسشنامه براى ترجمه در نظر كرفته شد. جهت ترجمه ابزار در مطالعه حاضر كليه كامهاى

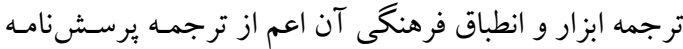
از زبان اصلى به زبان هدف، بر كردان نسـخه ترجمـه شـده از زبـان هـدف بـه زبـان اصـلى و اعتباريـابى برسشــامه و تهيـهـ كزارش نهايى انجام شد. جهت ترجمه ابزار از زبان اصلى بـهـ زبان فارسى، از كمكك و مساعدت ب نفــ از اسـاتيد آشــا بـه زبان انخكليسى كه تسلط كامـل بـه هـر دو زبـان و فـن ترجمـهـ داشته و در زمينه متون بزشكى فعاليت داشتند، استفاده شـد. ترجمه بر گشتى نيز با كمكك ب نفر ديخـر كه آشـنا بـه زبـان انكُليسى و فارسى هستند، انجام شد. بعد از ترجمه باز گشتى، محققين و مترجمين ترجمه بر گشتى ابزار و نسخه اصسلى آن را با يكديخر مقايسه كردنـد و اصـلاحات جزئسى در ترجمـه ابزار به زبان فارسى براى دركك بهتر ابـزار اعمـال كردنـــ. بـا

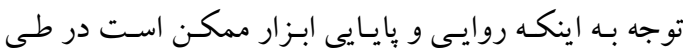
فرايند ترجمه تحت تأثير قرار كيرد، از اينرو بعـد از ترجمـهـ ابزار كليه مراحل زيـر جهـت تائيـد روايسى (روايسى صـورى كيفى، روايى محتواى كيفى و روايسى سـازه از نسوع تحليـل عاملى تأيدى) و يايايى (همسانى درونى و ثبات زمانى) ابزار

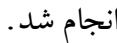

تحليل دادهها: براى تجزيه و تحليل دادههـا از نـرمافزارهـاى (IBMC) Corp., Armonk, NY, USA) Y نسخه ISPSS

Scientific Software International ) LISREL , P > نسخه N/1 استفاده شد. در كليه تحليل ها Inc., Y..V V هـ • • معنى دار در نظر كرفته شد.

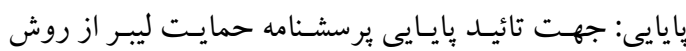

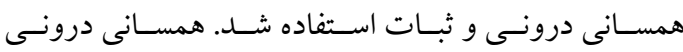

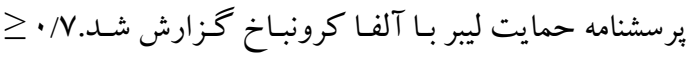
م جهت تائيد همسانى درونى ابزار قابل قبول در نظر گرفته شد. جهت بررسـى ثبـات زمـانى ابـزار از رويكـرد آزمـون -

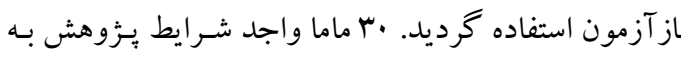
فاصـله دو هفتـه دو بــار برسشــامه حمايست ليبـر را تكميـل
حمايت ليبر را كه توسط Sauls و همكـاران در سـال F...r طر احى شده بود( (ه))، اندازه گيرى مى كرد.

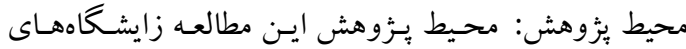
بيمارسـتانهـاى دانشـاهـاه علـوم بز شـكى ايـران (اكبر آبـادى، رسـول اكرم، فيروز آبـادى، فيروز گر، امـام سـجاد شهريار،

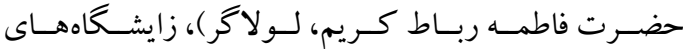
بيمارسـتانهـاى دانشـكاه علـوم يزشـكى تهـران (آرش، امـام

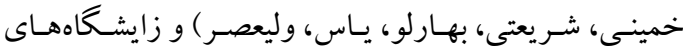
بيمارستانهاى دانشكاه علوم بزشكى شهيد بهشـتى (مهديـه،

$$
\text { امام حسين، شهداى تجريش) بود. }
$$

اندازه نمونه: به منظـور تعيسين نمونـه از ماماهـايى كـه سـابقه كارى بالاى 9 ماه، عدم مححـدوديت حر كتى شــاخته شـده، عدم مسؤليت اجرايى و همجينين در حال كذر اندن دورههاى آموزشى ارتقا دهنده رفتارهاى حمايتى ليبر مانند كلاسهاى

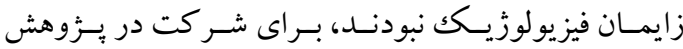

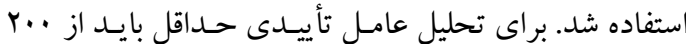
نمونه استفاده شود(IV) ( ) (IV). ملاحظات اخلاقى: تحقيق حاضر با تصويب و تأييديه كميته

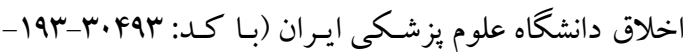

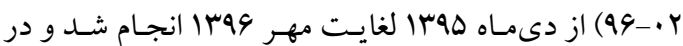
طــول انجـام تحقيـق، اهـــاف يــروهش و محرمانـهـ بــودن اطلاعات به سمع و نظر شـركت كنتـد كان رسـيد و رضـايت آنها براى شر كت در مطالعه كرفته شد. اندازهگيرى/ابـزار: منظور از حمايـت ليبـر در ايسن يـروهش امتيازى است كه ماماها از يرسشنامه حمايت ليبر كسب مى كنند. اين برسشنامه در سال F ... توسط Sauls و همكـاران rV بهورت خود خزارش دهى طراحى شده است و شـامل كويه است كه بـر اسـاس ليكرت و گزينـهاى نمـره كـذارى مىشود در مجموع ايـن ها| امتيـاز دارد و رفتـار حمـايتى را در جهـار حيطـه عـاطفى، لمسـى، اطلاعـاتى و طرفـدارى از تصـميمات زائسو مسىسـنجد و در نهايـت رفتـار حمـايتى بـهـ صـورت ضـعيف (امتيـاز FF- •)، متوسـط (امتيـاز خوب (امتياز هس|- •ه) گزارش مى شود(ها ). 
تحليل عاملى تأييدى: با توجه به اينكه در اين مطالعه، هـدف تائيد روايى ابزار ترجمه شده فارسى بوده است، از ايسنرو در بخش روايى سازه از روايى سازه از نوع تأييدى استفاده شـد. تحليل عاملى تائيدى بـا اسـتفاده از بـر آورد حسداقل مربعـات وزنى براى ارزيابى اينكه مدل ارائه شده مناسب با داده هـاى مشاهده شده هستند، انجام شد. به طور كلى در تحليل عاملى تأييدى روابط بين عامل هاى ينهـان و متغيرهـاى قابـل انــازه كيرى مشخص است و از اين طريق معنىدارى و شـدت ايسن روابط تعيين مىشود. شاخصهاى برازش و مقادير قابل قبول آنها كه در اين تحليل مورداستفاده قرار كرفت شـامل ايسن موارد بود: آماره نيكويى بـرازش كـاى دو ( degrees / كمتر از ه، RMSEA (of freedom(df) همجنين شاخص نيكو يى برازش ( GFI")، شاخص مقايسـه -

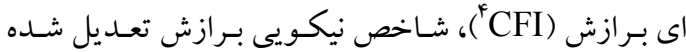

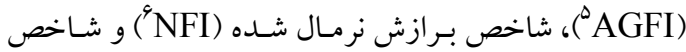

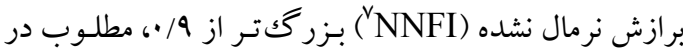

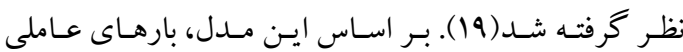
استاندارد شده بالاى س/ • ميزان بار عاملى متوسط تا قوى در

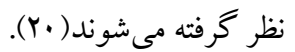

يافته ها

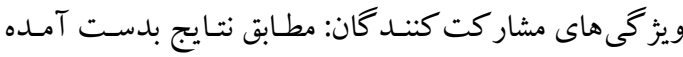
ميانگين سن افر اد مورد مطالعه MF/AF سال بـود، در رابطـه بـا

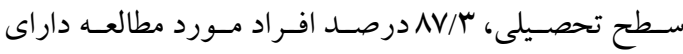
مدرك كارشناسى بودند. همجِنين نتايج بيانگر ايـن بـود كـه

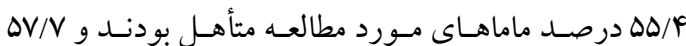
درصدشان تجربه كار مامايى كمتر از هال سال داشتند. يايايى: ضريب آلفاى كرونباخ به منظور بررسى همسانى درونى :برسشنامه حمايت ليبر محاسبه شد. مقدار ضريب

\footnotetext{
${ }^{2}$ Root Mean Square Error of Approximation

${ }^{3}$ Goodness of Fit Index

${ }^{4}$ Comparative Fit Index

${ }^{5}$ Adjusted Goodness of Fit Index

${ }^{6}$ Normed Fit Index

${ }^{7}$ Non-Normed Fit Index
}

كردند. ضريب اسييرمن بزركت تر و مساوى V/• بـه عنوان نتيجه رضايت بخش در نظر گرفته شد. روايى: روايى ابزار با اسـتفاده از تركيبى از روايسى صـورى، روايى محتواو روايى سازه از نوع تحليل عامل تائيدى مـورد بررسى قرار كرفت. روايى صورى كيفى: در مطالعه حاضر، جهت بررسى روايس

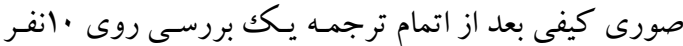
(كارشناس مامايى) انجام شد. در اين روايى كويههـاى ابزار از جهت سـطح دشـوارى (دركك عبـارات) و ابهام (احتمـال وجود برداشـتهـاى اشـتباه از عبـارت و يـاوجـود نارسـايى معانى كلمات) بررسى شـــ از مشـاركت كنـــــان خواستهـ شد گويههاى ابزار با صداى بلند در دلشان بخوانند و كويهها

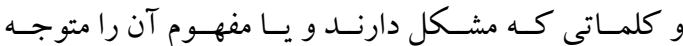

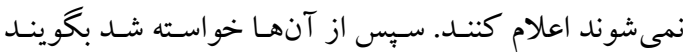

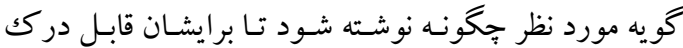
باشد و سيس وير ايش مجدد انجام شد. روايسى محتـواى كيفـى: روايسى محتـواى برسشـنامه در ايسن مرحله توسط ·ل انفـر از ارزيابـان خبـره و مطلع بـه موضسوع يزٔوهش و متدولوزى تحقيق كه عضو هيئت علمسى دانشـاه

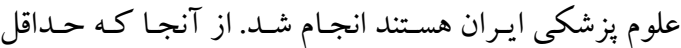
تعداد ارزيابان بر طبق جدول لاوشه' (1N) ينج نفر است، لـذا •ا نفر متخصص مسلط به موضوع تحقيـق و ابزارسـازى و از اعضاء هيئت علمى دانشگاه كه سابقه بزُوهش در ايـن زمينـه را داشتند انتخـاب و ابـزار در اختيـار آنـان قـرار گرفـت و از آنان درخواست شد تا بس از مطالعه دقيق ابزار، ديدگاههـاى اصلاحى خود را بهصورت مبسوط و كتبـى ارائه نماينـد. در اين بررسى از آنهـا خواسـته شـد ابـزار را از جهـت رعايـت دستور زبان، استفاده از كلمات مناسب، امتيازدهى مناسـبـ و زمان مناسب براى تكميل ابزار بررسى كنند. به دنبال دريافت

$$
\text { نظرات آنها يرسشنامه اصلاح شد. }
$$

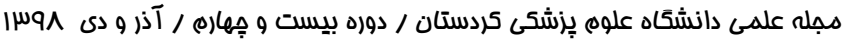


روش حداكثر احتمال و به منظور بررسى برازش مدل از

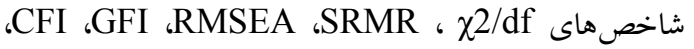
NFI و NFI ،AGFI

شاخصهاى برازندگى مدل ارائه شده از برازش مطلوبى برخوردار بود و مدل مفروض را تأييد كردند(جدول (1). همانطور كه در شكل ا نشان داده شده است، مدل مدرد يارامترها را بهخوبى بر آورد كرده است و قابل قبول است.
آلفاى كرونباخ براى كل برسشنامه 99/• به دست آمد كه

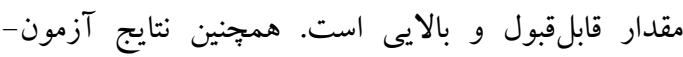
باز آزمون در بررسى ثبات زمانى ابزار با استفاده از ضريب

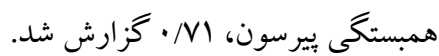
روايى برسشنامه حمايت ليبر از نظر صورى و محتوا تأييد شد، همجنين نتايج حاصل از تحليل عاملى تأييدى بيانكر

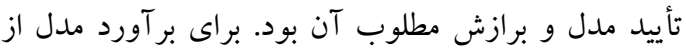

\begin{tabular}{|c|c|c|c|c|c|c|c|c|c|}
\hline$x^{2}$ & $\mathrm{df}$ & $\mathrm{X}^{2} / \mathrm{df}$ & RMSR & RMSEA & CFI & NFI & NNFI & GFI & AGFI \\
\hline$q V F / r q$ & MTY & $r / \cdots v$ & . &.$/ .9 \vee$ & .194 & .194 &.$/ 94$ &.$/ V \Delta$ &.$/ V$. \\
\hline
\end{tabular}

ارتباط همه كويهها از نظر آمارى معنىدار شناخته شد ( ( • • P P).

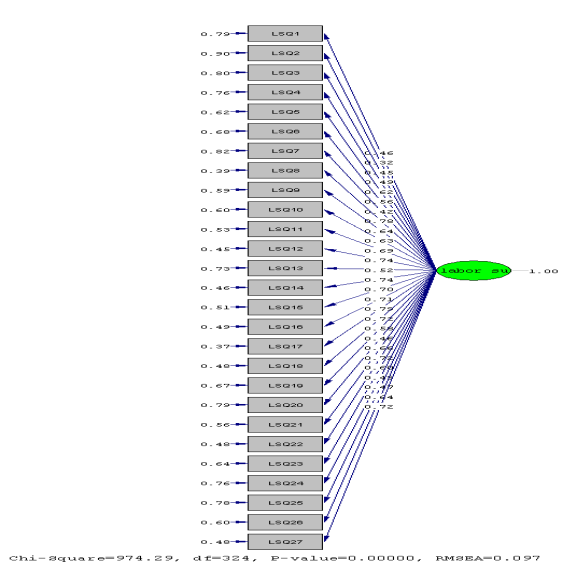

شكل 1. نمودار مسير براى تحليل عاملى تأييدى و ساختار عاملى آن 
روايـى صـورى و محتـو ايى نســه فارسسى ابـزار رفتارهـاى

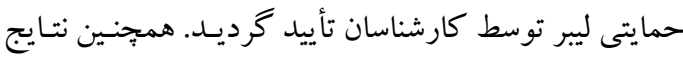
حاصـل از انسدازهخيــى كمى شـاخص روايـى در مطالعـه Sauls، تأييدى بر صحت گفتههاى كارشناسـان در رابطه بـا روايى صورى و محتواى ابزار بود(ها)، كـه در تحقيق مـا بـهـ

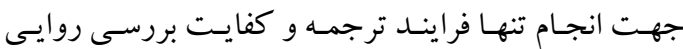

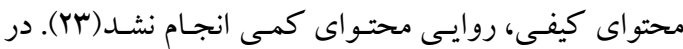

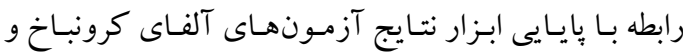

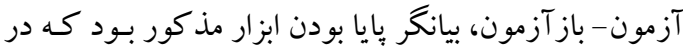

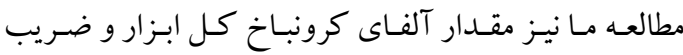
همبستخى آزمون -بـاز آزمون مطابق بـا يافتههـاى Sauls

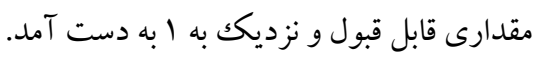
در مطالعهاى ديخر، HOA (ه) (Y) به بررسى عوامل مـرتبط با رفتارهـاى حمايتى ليبر در سـه بيمارستان واقع در شـمال

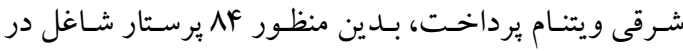
بخش زايمان انتخاب شدند. HOA ابزار را در سه مرحلـه بـه

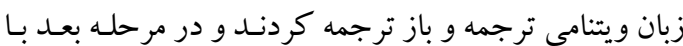

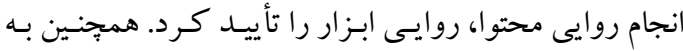
منظسور بررسى بايسايى ابـزار، آزمـون همسـانى درونسى، 10

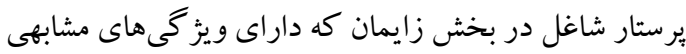

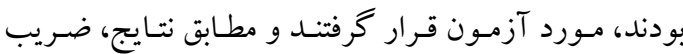

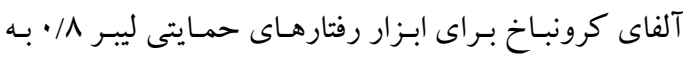
دست آمد(Y). نتايج حاصل از يافتههـاى مـا مبنى بـر تأييد

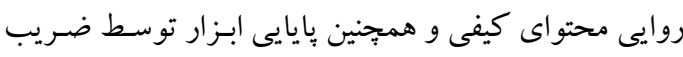

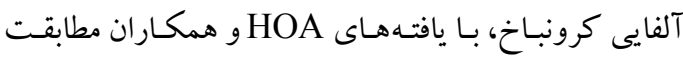

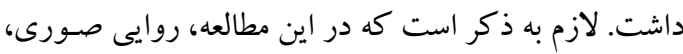

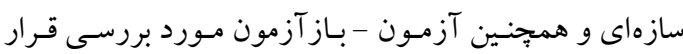
نخرفته بود كه از اين لحاظ قابل مقايسه با تحقيق حاضر نبود.

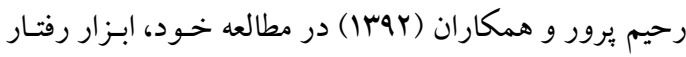

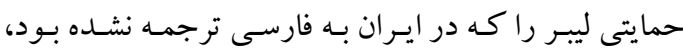
توسط دو فرد مسلط به زبان انخليسى به زبان فارسى ترجمه دئه

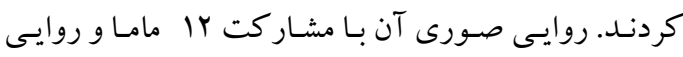

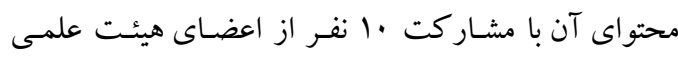

در يُوهش حاضر، روان سنجى نسخه فارسى ابزار رفتارهاى حمايتى ماما حين ليبر ارزيابى شد. مطابق نتايج روايى صورى و محتواى ابزار توسط كارشناسان تأييد شد. همجينين نتايج حاصل از تحليل عاملى تأييدى، نشان داد كه ابزار مورد مطالعه ساختار مناسبى دارد. پايايى ابزار توسط آزمون همسانى درونى (ضريب آلفاى كرونباخ) 99/ • محاسبه شد، كه بيانگر بايايى مناسب ابزار بود و زمانى ابزار از بايايى مناسبى برخوردار است كه ضريب آلفاى كرونباخ بزركت يا مساوى V/· باشد(Y). همجنين ضريب همبستخى بيرسون توسط آزمون- باز آمون ال/ • به دست آمد كه تأييدى بر

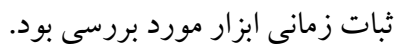

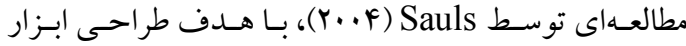
مذكور و بررسى روايى و وبايـايى آن در آمريكا انجام شـد. ابززار در دو بخـش طر احى شــ؛ بخـش اول ميزان اهميـت رفتارهاى حمايتى و بخش دوم به كارگيرى آن رفتارها بود. LSQ در ابتدا شامل بَ سؤال بود. نتايج حاصل از يافتههـاى بخش اول تحقيق در رابطه بـا روايسى بـه صـورت هـمزمـان (Concurrent Validity)

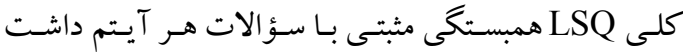

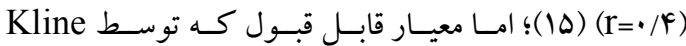

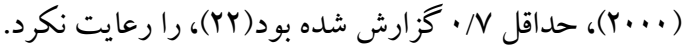
بـهنظظور بررسى بايـايى ابزار از روش آزمـون-بـاز آزمون

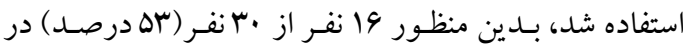

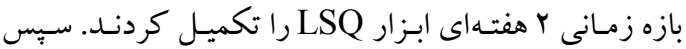
ضريب همبستخى بيرسون، هـ/ • محاسبه شـد كـه از حـداقل مقدار تعريف شده V/ توسط Waltz و همكاران در سـال 1991 بيشتر بود و مؤيد بِيايايى ابزار مـورد مطالعه بـود(T).

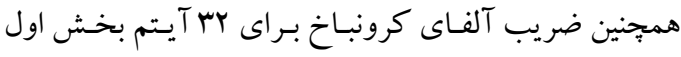

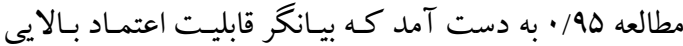

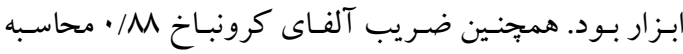

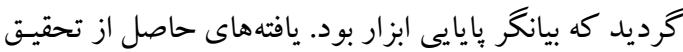

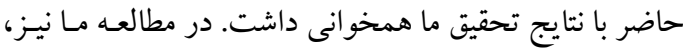




\section{نتيجه كيرى}

با توجـه بـه نتـايج حاصـل از تحقيق حاضـر مى توان نتيجهـ

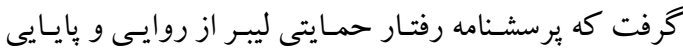
قابل قبولى براى بررسى رفتار حمايتى ماماها برخوردار بود؛؛

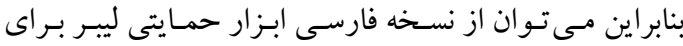
بررسى رفتارهاى حمايتى ليبر در داخل كشور استفاده كرد.

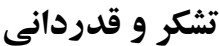

نويسند كان مقاله، بدين وسيله مر اتب سياس و قدردانى خـود را از كميته تحقيقات دانشگاه علوم يزشكلى ايـران بـه دليـل حما يـت مـادى و معنــوى و همجنــين ماماهـاى شـاغل در

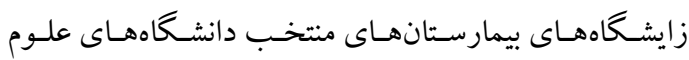
يزشكى شهر تهـران كه در ايـن مطالعه مشـار كت نمودنــد،

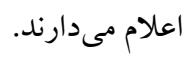

خبره كه بـه زبـان انگليسى نيـز مسـلط بودنـد، انجـام شـد.

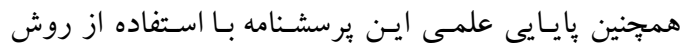
آزمون - باز آزمون باضريب همبستكى بيرسون AV/ • تائيد

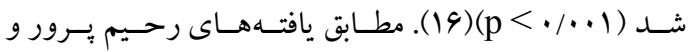
همكاران (rarا)، روايسى محتوا و صـورى كيفى در حين ترجمه تأييد شد و تفاوت جندانى بين نسخه اصلى و ترجمـه شده وجود نداشت كه با يافته هـاى تحقيق حاضـر مطابقـت

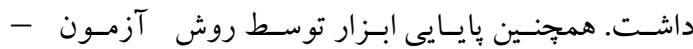
باز آزمون تأييد شد كه با يافته هـاى تحقيق مـا مبنى بـر بايـا بودن ابزار همخو انى داشت. بـا توجهه بـه لزوم انجام تحليل

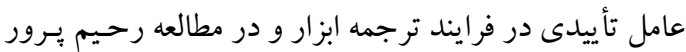

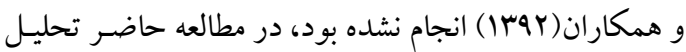

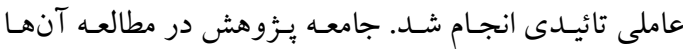
دانشجويان بودند كه ممكن است مهارت و تجربـه كافى در

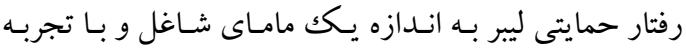

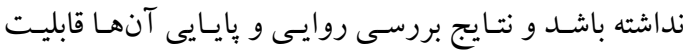

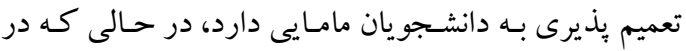
مطالعه حاضـر بررسى روانسـنجى ابزار در ميـان ماماهـاى بـاى شاغل در ليبر و با سطوح تحصيلى و سابقه كار متفاوت انجام شله. با اين حال، مطالعه حاضر همجِون ساير مطالعات، داراى نقاط ضعف و محدوديتهاى بود منجمله، در مطالعه حاضر فقط ماماهاى شاغل در بيمارستانهاى منتخب دانشكاههاى علوم بزشكى شهر تهران و در بيمارستانهاى

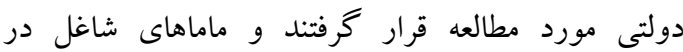

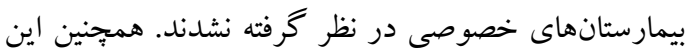
مطالعه فقط در سطح شهر تهران انجام شد و كل استان تهران و حومه، به دليل كمبود وقت و مشكلات بيشرو در نظر

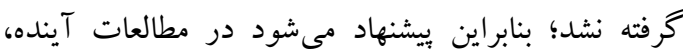

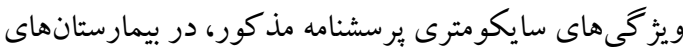
خصوصى و در يكك مطالعهاى جامع تر و كشورى انجام شود. 


\section{Reference}

1. Valiani M, Rezaie M, Shahshahan Z. Comparative study on the influence of three delivery positions on pain intensity during the second stage of labor. Iranian journal of nursing and midwifery research. $2016 \mathrm{Jul} ; 21(4): 372$.

2. HOA LT. FACTORS RELATED TO PROFESSIONAL LABOR SUPPORT BEHAVIORS AMONG INTRAPARTUM NURSES IN THE NORTHEAST OF VIET NAM (Doctoral dissertation, BURAPHA UNIVERSITY).

3. Dadshahi S, Torkzahrani S, Janati-Ataie P, Nasiri M. Does continuous labor support by midwife make a difference in delivery outcomes?. The Iranian Journal of Obstetrics, Gynecology and Infertility. 2018;20(12):67-76.

4. Martin JA, Hamilton BE, Sutton PD, Ventura SJ, Menacker F, Kirmeyer S, Munson ML. Births: final data for 2005. National vital statistics reports. 2007 Dec 5;56(6):1-03.

5. Hodnett ED, Gates S, Hofmeyr GJ, Sakala C. Continuous support for women during childbirth. Cochrane database of systematic reviews. 2012(10).

6. Yuenyong S, O'brien B, Jirapeet V. Effects of labor support from close female relative on labor and maternal satisfaction in a Thai setting. Journal of Obstetric, Gynecologic, \& Neonatal Nursing. 2012 Jan;41(1):45-56.

7. MORHASON-BELLO IO, Adedokun BO, Ojengbede OA, Olayemi O, Oladokun A, Fabamwo AO. Assessment of the effect of psychosocial support during childbirth in Ibadan, south-west Nigeria: A randomised controlled trial. Australian and New Zealand Journal of Obstetrics and Gynaecology. 2009 Apr 1;49(2):145-50.

8. Lemola S, Stadlmayr W, Grob A. Maternal adjustment five months after birth: the impact of the subjective experience of childbirth and emotional support from the partner. Journal of reproductive and infant psychology. 2007 Aug 1;25(3):190-202.

9. Creedy DK, Shochet IM, Horsfall J. Childbirth and the development of acute trauma symptoms: incidence and contributing factors. Birth. 2000 Jun;27(2):104-11.

10. Larkin P, Begley CM, Devane D. 'Not enough people to look after you': an exploration of women's experiences of childbirth in the Republic of Ireland. Midwifery. 2012 Feb 1;28(1):98-105.

11. Ith P, Dawson A, Homer CS. Women's perspective of maternity care in Cambodia. Women and Birth. 2013 Mar 1;26(1):71-5.

12. Dunne CL, Fraser J, Gardner GE. Women's perceptions of social support during labour: Development, reliability and validity of the Birth Companion Support Questionnaire. Midwifery. 2014 Jul 1;30(7):847-52.

13. Vakili M.M. The methods and tools for data collection in applied research (freeware). zahedan journal of research in medical sciences. 2009 November 8;12(4):1-2.

14. Doward LC, Meads DM, Thorsen H. Requirements for quality of life instruments in clinical research. Value in Health. 2004 Sep; 7:S13-6.

15. Sauls DJ. The labor support questionnaire: Development and psychometric analysis. Journal of Nursing Measurement. 2004 Oct 1;12(2):123-32.

16. Vasegh Rahimparvar F, Nasehi G, Khakbazan Z, Kazemnezhad A. Design, implementation and evaluation of educational program in continuous labor support to midwifery students. The Iranian Journal of Obstetrics, Gynecology and Infertility. 2013;16(79):10-7.

17. Hinkin TR. A review of scale development practices in the study of organizations. Journal of management. 1995 Oct;21(5):967-88.

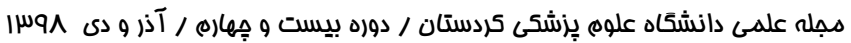


18. Moore EE, Romaniuk H, Olsson CA, Jayasinghe Y, Carlin JB, Patton GC. The prevalence of childhood sexual abuse and adolescent unwanted sexual contact among boys and girls living in Victoria, Australia. Child abuse \& neglect. 2010 May 1;34(5):379-85.

19. Bentler PM, Bonett DG. Significance tests and goodness of fit in the analysis of covariance structures. Psychological bulletin. 1980 Nov;88(3):588.

20. Cohen J. Statistical power analysis for the behavioral sciences. $2 \mathrm{nd}$.

21. Arafat SY. Validation study can be a separate study design. International Journal of Medical Science and Public Health. 2016 Nov 1;5(11):2421-2.

22. Kline P. The Handbook of Psychological Testing. London: Routlege. Knoef, M., de Vos, $\mathrm{K}$. (in press) The representativeness of LISS, an online probability panel. 2000.

23. Waltz CF, Strickland O, Lenz ER. Measurement in nursing research: FA Davis Company. 